\title{
Will the source of demand shifts please stand up? Steady demand or Acceleration
}

Citation for published version (APA):

Dupuy, A. (2003). Will the source of demand shifts please stand up? Steady demand or Acceleration. ROA. ROA Research Memoranda No. 4E https://doi.org/10.26481/umaror.200304E

Document status and date:

Published: 01/01/2003

DOI:

10.26481/umaror.200304E

Document Version:

Publisher's PDF, also known as Version of record

\section{Please check the document version of this publication:}

- A submitted manuscript is the version of the article upon submission and before peer-review. There can be important differences between the submitted version and the official published version of record.

People interested in the research are advised to contact the author for the final version of the publication, or visit the DOI to the publisher's website.

- The final author version and the galley proof are versions of the publication after peer review.

- The final published version features the final layout of the paper including the volume, issue and page numbers.

Link to publication

\footnotetext{
General rights rights.

- You may freely distribute the URL identifying the publication in the public portal. please follow below link for the End User Agreement:

www.umlib.nl/taverne-license

Take down policy

If you believe that this document breaches copyright please contact us at:

repository@maastrichtuniversity.nl

providing details and we will investigate your claim.
}

Copyright and moral rights for the publications made accessible in the public portal are retained by the authors and/or other copyright owners and it is a condition of accessing publications that users recognise and abide by the legal requirements associated with these

- Users may download and print one copy of any publication from the public portal for the purpose of private study or research.

- You may not further distribute the material or use it for any profit-making activity or commercial gain

If the publication is distributed under the terms of Article $25 \mathrm{fa}$ of the Dutch Copyright Act, indicated by the "Taverne" license above, 


\section{Will the source of demand shifts please stand up? Steady demand or Acceleration}

ROA-RM-2003/4E

Arnaud Dupuy

Research Centre for Education and the Labour Market

Faculty of Economics and Business Administration

Maastricht University

Maastricht, July 2003 
ISBN 90-5321-376-7

Sec03.133.doc 


\section{Contents}

Page

Abstract

i

1. Introduction 1

2. The Data 2

3. The Model 4

4. Wage differentials in the Netherlands: 2000-2020 10

5. Conclusion 12

References $\quad 13$

$\begin{array}{ll}\text { Appendix A } & 16\end{array}$

$\begin{array}{ll}\text { Appendix B } & 17\end{array}$ 



\begin{abstract}
In this paper we analyse wage inequality and decompose the shifts in the relative demand for skilled workers into a skill-biased technological change effect and a capital-skill complementarity effect. We estimate the skill premium in the Netherlands from 1969 to 1996 and find that between 1969-1982 demand shifts are due to skill-biased technological change only while since 1982, the capital-skill complementarity explanation accounts for $1 / 3$ of the demand shifts. Using forecasts of the relative supply of skilled workers we predict the skill premium to 2020 for different scenarios of the change in the stock of capital. In our worst scenario, if the stock of capital increases steadily at a yearly rate of 5\% (its highest historical rate between 1982-1996) wage inequality would rise by $21 \%$ in 2020 . This rising wage inequality results from shifts in the relative demand for skilled workers initiated for $3 / 4$ by the capital-skill complementarity. We conclude that the position of unskilled workers is less undermined by skill-biased technological change than it is by persistently cheaper capital and their ever decreasing share in total costs.
\end{abstract}

JEL Classification: D33, J11 and J38.

Keywords: Wage inequality, technological change and capital-skill complementarity.

\title{
Acknowledgement
}

We would like to thank Frank Cörvers, Bart Golsteyn and Philip Marey for helpful comments on earlier drafts. 



\section{Introduction}

Since the second world war, developed countries have observed a growing wage inequality between skilled and unskilled labour. Though wage inequality rose more sharply in the US and the UK, this stylised fact characterises many European countries too. The rise in wage inequality is accompanied by a steadily increasing relative supply of skilled workers, suggesting that shifts in the relative demand for skilled workers have off-set the shifts in relative supply, e.g. Katz and Murphy (1992).

Although, the related literature seems to agree with the idea that wage inequality rises because of faster shifts in the relative demand for skills than in the relative supply, the source of the shifts in the relative demand for skills is the subject matter of divergence of opinion. It resumes to two main components. The skillbiased technological change explanation led by, among others, Bound and Johnson (1992) and the capital-skill complementarity explanation advanced by Krusell et al. (2000).

In this paper we analyse wage inequality and decompose the shifts in the relative demand for skills into a skill-biased technological change effect and a capital-skill complementarity effect. We estimate simultaneously the share equations of capital, skilled and unskilled labour using non-neutral technological change. ${ }^{1}$ These share equations are derived from a translog production function and therefore do not require to impose ex ante restrictions on the substitution elasticities between inputs and their separability. We estimate the skill premium in the Netherlands from 1969 to 1996 . We find that between 1969-1982 demand shifts are due to skillbiased technological change only while since 1982, the capital-skill complementarity explanation accounts for $1 / 3$ of the shifts in the relative demand for skills and the

\footnotetext{
${ }^{1}$ See Binswanger (1974) for instance. We expect technological change to be skilled labour augmenting or unskilled labour saving.
} 
SBTC for $2 / 3$. The effect of capital-skill complementarity is due to i) an acceleration in the growth rate of the stock of capital, from $0 \%$ to $4.9 \%$ and ii) a constant decrease in the share of unskilled workers at an annual rate of $2.2 \%$.

Using forecasts of the relative supply of skilled workers, we predict the relative wage of skilled workers to 2020 for different scenarios of the change in the stock of capital. If the stock of capital increases steadily at a yearly rate of $5 \%$ (its rate between 1982-1996) wage inequality would rise by $21 \%$ in 2020 because of shifts in the demand for skilled workers due, for up to $3 / 4$, to the capital-skill complementarity. However, if the stock of capital grows at its average annual rate observed between 1969-1996, i.e. $2.7 \%$, wage inequality would increase by $13 \%$ and $60 \%$ of the demand shifts would be induced by the capital-skill complementarity. Regardless of the scenarios, the large impact of the capital-skill complementarity is not only due to the increase in the stock of capital but also to the constant decrease of the share of unskilled workers.

The paper is organised as follows. In section 2 we discuss the data used for empirical analysis. In section 3 we present the quantitative methodology and the estimation results. In section 4, we predict the developments in wage inequality and present different deterministic scenarios. Section 5 concludes.

\section{The Data}

The data we use consists of annual time-series of capital and labour between 1969 and 1996 for the Netherlands. ${ }^{2}$ We make use of the series of labour costs available from the National Income series and capital costs (i.e. measured by the level of investments in fixed assets) to derive the share of labour and capital in total costs. The share of labour is subsequently decomposed into the share of skilled and

\footnotetext{
${ }^{2}$ The data can be obtained from the author's website, http://www.fdewb.unimaas.nl/roa.
} 
unskilled labour using the respective series on wages and quantities.

To obtain the series on the stock of capital we use the standard measure of investment in fixed assets expressed in 1969 prices from the National Income series collected by the Central Planning Bureau (CPB). The series of capital stock are normalised to 1 in 1969.

The stock of capital remains roughly constant through 1982 and grew at a 4.9 annual percent rate thereafter as illustrated in figure 1. The price of capital is steadily decreasing since 1982 as can be seen from figure 2 .

$<$ Figure $1><$ Figure $2>$

Since we are interested in developments in the relative skill premium we distinguish between skilled and unskilled labour. We use the time-series collected by the Dutch Central Bureau for the Statistics, CBS (1999). ${ }^{3}$ We define low skilled workers by workers with primary or secondary education and skilled workers by higher educated workers. The relative supply of skilled workers is the ratio of the number of skilled workers to the number of unskilled workers. Wages are based on gross hourly wages and we define wage inequality as the ratio of the wages of skilled workers and unskilled workers. The supply of both skilled and unskilled workers is normalised to 1 in 1969 .

The data indicates that the supply of skilled workers has been multiplied by a factor 3.5 in the period of observation while the supply of unskilled workers remained fairly stable, as indicated in figure 1 . The relative wage of skilled workers decreased at an average annual rate of $1.4 \%$ between 1969 and the mid 80's with a markedly higher annual rate in the beginning of the 80's. Since 1992 the relative wage inequality seems to be rising again at a annual rate of $0.8 \%$ as shown in figure

3.

\footnotetext{
${ }^{3}$ See Jacobs (2003) for more details on this data set. The labour series and wage series we use are simply obtained from Table $A 1$ of the appendix in Jacobs (2003), by aggregating $l_{u}=l_{b}+l_{l}+l_{m}$ for unskilled labour and weighting $w_{u}=\left(l_{b} w_{b}+l_{l} w_{l}+l_{m} w_{m}\right) / l_{u}$ for the unskilled wage.
} 
$<$ Figure $3>$

\section{The Model}

In the literature related to the rising wage inequality, two main explanations ${ }^{4}$. are often put forward. The skill-biased technological change (see e.g. Bound and Johnson (1992), Berman et al. (1994) and Autor et al. (1998) and Acemoglu (2002)) explanation is the most dominant in the literature. The arguments reads as follows. New technologies are relatively more complementary with skilled workers than with unskilled workers. These new technologies when used in the production process therefore shift the relative demand for skilled workers upward.

The second explanation finds roots in the capital-skill complementarity in production. ${ }^{5}$ Skilled workers are more complementary to capital than unskilled workers such that, a decrease in the price of capital shifts the relative demand of skilled workers upward, e.g. Krusell et al. (2000). The explanation of rising wage inequality by the capital-skill complementarity has often been rejected because of its apparent inconsistency with a constant share of capital in the economy. ${ }^{6}$ However, though an aggregate production function with a unitary elasticity of substitution between capital and labour (aggregate of skilled and unskilled labour) ensures the constancy of the share of capital, there are more flexible forms of aggregate production function satisfying the postulate of the constant share of capital. Indeed, a production function with a greater-than-unity elasticity of substitution accompanied by a labour

\footnotetext{
${ }^{4} \mathrm{~A}$ third explanation put forward in the literature is the increasing international trade. Countries with high relative supply of skilled workers specialise in skill intensive production increasing the relative demand for skilled workers. However, several agurments against this explanation are raised, e.g. the relative demand shifts took place in all industries (tradeable and nontradeable industries), see Johnson (1997). Acemoglu (2002) argues that "increased international trade by itself is not the cause of the changes in the US wage structure, but trade may have been an important factor in the rise of wage inequality by affecting the degree of skill bias of technical change," p.52. Hence, SBTC accelerates due to trade opening.

${ }^{5}$ See e.g. Rosen (1968), Griliches (1969), Grant and Hamersmesh (1979) and Hamermesh (1993).

${ }^{6}$ See Jacobs (2003) for an exposition of this argument.
} 
augmenting technological change would be consistent with constant shares of labour and capital, see e.g. Brown and De Cani (1963), Kennedy (1964), David and van de Klundert (1965), Sato (1970) and Yuhn (1990).

\section{Quantitative Methodology}

In this paper we consider both the skill-biased technological change and the capital-skill complementarity explanation of shifts in the relative demand for skilled workers.

We approximate the 3 -factor ${ }^{7}$ production function, $Y=F\left(L_{s}, L_{u}, K\right)$, by a translog form: ${ }^{8}$

$$
\begin{aligned}
\ln Y= & \alpha_{0}+\alpha_{t} \ln t+\alpha_{K} \ln K+\sum_{j} \alpha_{j} \ln L_{j} \\
& +\frac{1}{2} \sum_{j} \beta_{K, j} \ln K \ln L_{j}+\frac{1}{2} \sum_{j} \sum_{k} \beta_{j, k} \ln L_{j} \ln L_{k} \\
& +\gamma_{K, t} \ln K \ln t+\sum_{j} \gamma_{j, t} \ln L_{j} \ln t+\frac{1}{2} \gamma_{t, t} \ln ^{2} t
\end{aligned}
$$

where $Y$ is output, $L_{j}$ are labour inputs (number of workers skilled workers $j=1$ and unskilled workers $j=2$ ), $K$ is capital stock, $t$ is a time capturing time dependent technological changes, the Greek letters are technology parameters.

We assume that the production function of specification (1) is well-behaved so that it is homogeneous of degree one in inputs quantities. This implies imposing the following restrictions on the parameters:

\footnotetext{
${ }^{7}$ Let the first 2 input factors be skilled and unskilled labour and the $3^{r d}$ be capital stock

${ }^{8}$ Note that we have dropped time indexes for the sake of convenience.
} 


$$
\begin{aligned}
\alpha_{K}+\sum_{j} \alpha_{j} & =1 \\
\sum_{j}\left(\beta_{K, j}+\sum_{k} \beta_{j, k}\right) & =\sum_{j} \beta_{j, K}=\sum_{j} \beta_{j, k}=\sum_{j} \beta_{K, j}=\sum_{j} \beta_{k, j}=0 \\
\beta_{j, k} & =\beta_{k, j} \text { and } \beta_{K, j}=\beta_{j, K} \\
\sum_{j} \gamma_{j, t}+\gamma_{K, t} & =0
\end{aligned}
$$

With the assumption of competitive input markets, $\partial F / \partial L_{j}=w_{j}$ and $\partial F / \partial K=$ $r$, the factor share equations are derived from the 3 output elasticity equations as follows:

$$
\begin{aligned}
\partial F / \partial L_{j} & =w_{j} L_{j} / Y=S_{j}, \forall j \\
\partial F / \partial K & =r K / Y=S_{K}
\end{aligned}
$$

where $w_{j}$ and $S_{j}$ are respectively the wage and cost share of labour $j$ and $r$ and $S_{K}$ the price and cost share of capital.

Equating the costs shares to the logarithmic marginal products yields:

$$
\begin{aligned}
S_{j} & =\alpha_{j}+\beta_{j, K} \ln K+\sum_{k} \beta_{j, k} \ln L_{k}+\gamma_{j, t} \ln t, \forall j \\
S_{K} & =\alpha_{K}+\beta_{K, K} \ln K+\sum_{j} \beta_{K, j} \ln L_{j}+\gamma_{K, t} \ln t
\end{aligned}
$$

Any deviations of the cost shares from the logarithmic marginal products are assumed to be errors in cost minimising behaviour captured in the empirical estimation by a classical additive disturbance for each of the cost shares equations. 
We estimate simultaneously the share equations of capital, skilled and unskilled labour ${ }^{9}$ using non-neutral technological change $(8 \text { and } 9)^{10}$ using the iterative Zellner method. ${ }^{11}$

The estimates of equations 8 and 9 can then be used to predict ex post the relative wage inequality.

$$
\begin{aligned}
\frac{\widehat{w_{s}}}{w_{u}} & \equiv \frac{S_{s}}{S_{u}} \frac{L_{u}}{L_{s}} \\
& =\frac{\widehat{\alpha}_{s}+\widehat{\beta}_{s K} \ln K+\widehat{\beta}_{s u} \ln L_{u}+\widehat{\beta}_{s s} \ln L_{s}+\widehat{\gamma}_{s t} \ln t}{\widehat{\alpha}_{u}+\widehat{\beta}_{u K} \ln K+\widehat{\beta}_{s u} \ln L_{s}+\widehat{\beta}_{u u} \ln L_{u}+\widehat{\gamma}_{u t} \ln t} \frac{L_{s}}{L_{s}}
\end{aligned}
$$

Changes in the wage inequality can be decomposed into skill-biased technological change, substitution effect (or supply shifts) and capital-skill complementarity effect using equation 10 .

$$
\begin{aligned}
d \ln \frac{w_{s}}{w_{u}} \simeq & \frac{\partial \ln \frac{w_{s}}{w_{u}}}{\partial \ln t} \frac{1}{t}+\frac{\partial \ln \frac{w_{s}}{w_{u}}}{\partial \ln L_{s}} d \ln L_{s}+\frac{\partial \ln \frac{w_{s}}{w_{u}}}{\partial \ln L_{u}} d \ln L_{u}+\frac{\partial \ln \frac{w_{s}}{w_{u}}}{\partial \ln K} d \ln K \\
= & \left(\frac{\gamma_{s t}}{S_{s}}-\frac{\gamma_{u t}}{S_{u}}\right) \frac{1}{t}+ \\
& \left(\frac{\beta_{s s}}{S_{s}}-\frac{\beta_{u s}}{S_{u}}-1\right) d \ln L_{s}+\left(\frac{\beta_{u u}}{S_{u}}-\frac{\beta_{u s}}{S_{s}}+1\right) d \ln L_{u}+ \\
& \left(\frac{\beta_{s K}}{S_{s}}-\frac{\beta_{u K}}{S_{u}}\right) d \ln K
\end{aligned}
$$

\footnotetext{
${ }^{9}$ It is usually argued that factor prices rather than factor quantities should be considered as exogenous when using firm-level data and therefore a cost function should be estimated rather than a production function. As Varian (1984) p. 174 explains : "if the managers observe variables omitted in the model, then they certainly take that information into account when they determine their optimal choice of inputs." The estimates of the model will then be biased. Because of the endogeneity of input levels, an estimation procedure using instrumental variables is required. Berndt and Christensen (1973) find no signifficant differences in estimates between the Zellner method and the three stage least squares. Therefore, to avoid problems inherent in choosing instrumental variables, the Zellner method is prefered.

${ }^{10}$ One share equation, arbitrarily chosen, was dropped since identification problems result from the homogeneity restrictions. The translog parameters are though independent of the choice of which share equation to drop since we use the iterative Zellner-efficient estimation (see Berndt and Christensen 1973).

${ }^{11}$ See Zellner $(1962 ; 1963)$.
} 
The capital-skill complementarity effect on wage inequality can further be decomposed into an impulse due to changes in the stock of capital, i.e. $d \ln K$ and a multiplicative effect depending on the technological parameters of substitution between capital and skilled and unskilled labour and the distributive shares of skilled and unskilled labour. Since capital and unskilled workers are usually strong substitute, the parameter $\beta_{u K}$ is expected to be negative. Given the negativity of the $\beta_{u K}$ parameter, the comparative statics indicate that the smaller the share of unskilled workers the larger the capital-skill complementarity effect, ceteris paribus. The capital-skill complementarity effect depends on the distributive shares of skilled and unskilled labour in a way that resembles the "importance of being unimportant" Marshall's law, Marshall (1920). The smaller the share of unskilled workers the more affected they will be by changes in the stock of capital through the capitalskill complementarity.

\section{Empirical Results}

The estimates of the share equations are reported in table $1 .{ }^{12}$ As expected we find strong significant evidence for skill-biased technological change in the Netherlands. The annual rate of skilled labour augmenting is about $3.5 \%\left(\gamma_{s t}=0.035\right)$ in the period 1969-1996 while the annual rate of unskilled labour saving is nearly $1.6 \%$ $\left(\gamma_{u t}=-0.016\right)$. Also, we find significant evidence for a capital saving technological change at an annual rate of $0.7 \%$. Therefore, since the share of capital is roughly constant over time one might expect an elasticity between capital and labour larger than unity.

\footnotetext{
${ }^{12}$ Due to serial correlation, the bordered Hessian from the IZEF estimates was not negative definite for some data points. To ensure the monotonicity and convexity restrictions, we imposed some restrictions on the parameters. We proceed to a grid search for the parameters $\beta_{u u}$ and $\beta_{s k}+\beta_{u k}$ such that the prediction of the relative wage inequality is maximised, i.e. $\min \sum_{t}\left(\frac{\widehat{w_{s}}}{w_{u}}, t-\frac{w_{s}}{w_{u}}, t\right)^{2}$. The results, reported in table 5 in appendix $\mathrm{B}$, show that the problem is optimised for $\beta_{u u}=0.07$ and $\beta_{s k}+\beta_{u k}=0.02$.

The coefficients of the share of capital equation are derived from the homogeneity restrictions, equations 2, 3, 4 and 5 .
} 
Table 1: Parameter estimates of the share equations using IZEF.

\begin{tabular}{llcl}
\hline \hline$S_{s}$ & & $R^{2}$ & 0.87 \\
& $\alpha_{s}$ & $0.482^{* *}$ & $(0.010)$ \\
& $\beta_{s K}$ & $0.032^{* *}$ & $(0.010)$ \\
& $\beta_{s u}$ & $-0.057^{* *}$ & $(0.010)$ \\
& $\beta_{s s}$ & 0.025 & $(0.020)$ \\
& $\gamma_{s t}$ & $0.035^{* *}$ & $(0.007)$ \\
$S_{u}$ & & $R^{2}$ & 0.98 \\
& $\alpha_{u}$ & $0.269^{* *}$ & $(0.003)$ \\
& $\beta_{u K}$ & -0.012 & $(0.010)$ \\
& $\beta_{u u}$ & 0.070 & \\
$S_{K}$ & $\gamma_{u t}$ & $-0.016^{* *}$ & $(0.027)$ \\
& & & \\
& $\alpha_{K}$ & 0.243 & - \\
& $\beta_{K K}$ & 0.070 & - \\
\hline \hline (Standard-deviation) & & -0.019 & \\
& $\gamma_{K t}$ & & \\
& sig at 1\% & & \\
& & &
\end{tabular}

Table 2: Estimated Own price elasticities and Allen partial elasticities of substitution between capital, skilled and unskilled labour, using IZEF, in the Nethertlands 1969-1996.

\begin{tabular}{lrrr}
\hline \hline & Capital & Unskilled & Skilled \\
Capital & -0.87 & 1.95 & 0.70 \\
Unskilled & & -8.05 & 1.60 \\
Skilled & sim & & -3.26 \\
\hline \hline
\end{tabular}

We computed the Allen partial elasticity of substitution, ${ }^{13}$ i.e. AES, for the fitted median ${ }^{14}$ shares in the period 1969-1996. The results are consistent with earlier findings in the literature. ${ }^{15}$ In Allen's sense, capital is p-substitute with unskilled labour and gross p-complement with skilled labour. We find strong evidence for the relative capital-skill complementarity (1.95 versus 0.7$)$. This results suggests that both skill-biased technological change and capital-skill complementarity contribute to the shifts in the relative demand for skilled workers as the price of capital falls between 1969-96.

Our model enables us to decompose the relative increase in wage inequality into three effects. The substitution effect induced by the increased relative supply of

\footnotetext{
${ }^{13}$ See Allen (1938).

${ }^{14}$ See Appendix for computational details. The elasticity of substitution for all years are available upon request to the author.

${ }^{15}$ See Hamermesh (1992) and (1993) for an exhaustive overview of the literature.
} 
Table 3: Decomposition of wage inequality 1969-1982, 1982-1996.

\begin{tabular}{|c|c|c|c|c|c|c|}
\hline & SBTC & $\sigma_{K S}$ & Demand Shift & Substitution & Total & $S_{u}$ \\
\hline $69-82$ & 0.35 & 0.00 & 0.35 & -0.50 & -0.15 & $-2.6 \%$ \\
\hline $82-96$ & 0.11 & 0.06 & 0.17 & -0.27 & -0.10 & $-2.2 \%$ \\
\hline $69-96$ & 0.46 & 0.06 & 0.45 & -0.77 & -0.22 & $-2.4 \%$ \\
\hline
\end{tabular}

skilled workers, the effect resulting from the skill-biased technological change and the capital-skill complementarity effect. We split the period into two sub-periods, 1969-1981 and 1982-1996 characterised by drastically different growth in the stock of capital, i.e capital stock is roughly constant before 1982 and increases at an annual rate of $4.9 \%$ thereafter. We find that the period $1969-1982$ is characterised by a large impact of skill-biased technological change on wage inequality and no effect of the capital-skill complementarity as indicated in table 3. Although, since 1982, the magnitude of the capital-skill complementarity effect on wage inequality has accounted for $1 / 3$ of the demand shifts, the SBTC effect accounting for $2 / 3$. This is due to i) an acceleration in the growth rate of the stock of capital from $0 \%$ to $4.9 \%$ and ii) a constant decrease in the share of unskilled workers at an annual rate of $2.2 \%$.

\section{Wage differentials in the Netherlands: 2000-2020}

We make use of the supply forecasts for skilled and unskilled workers provided by CBS and CPB and used by Jacobs (2003). The data provides an estimation of the number of persons employable in the labour force from 2000 to 2020 . We make predictions of the relative wage of skilled workers using deterministic scenarios of the stock of capital.

The three deterministic scenarios we consider are: i) the stock of capital grows at an annual rate of 4.9 percent (that is it grows at the same pace it did during the period 1982-1996, Pk_high in figure 4) during the period 2000-2020, ii) it grows at 2.7 percent per year (i.e. $\mathrm{Pk} \_$med in figure 4) and iii) it remains constant (like in 
Table 4: Decomposition of wage inequality 2000-2020.

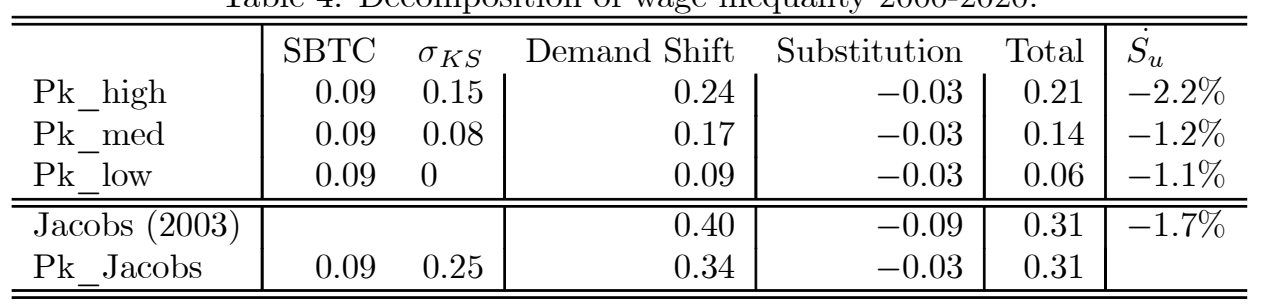

the period 1969-1982, Pk_const in figure 4).

The increase in wage inequality, as predicted by our model, varies from $21 \%$ in the worst scenario when capital stock rises 5 percent per year to $5.8 \%$ only when the stock of capital remains constant, as depicted in figure 4.

$<$ Figure $4>$

The decomposition of the relative increase in wage inequality into three effects indicates a moderate impact of skill-biased technological change on wage inequality compare to the capital-skill complementarity effect, as indicated in table 4 . The large impact of the capital-skill complementarity is not only due to the increase in the stock of capital but also to the constant decrease of the share of unskilled workers regardless of the scenarios.

Jacobs (2003) predicts an increase of $31 \%$ in wage inequality in 2020 due to a $40 \%$ increase in the relative demand in his baseline scenario, i.e. elasticity of substitution between skilled and unskilled labour is 1.4 and time-trend of $2 \%$. Accounting for the capital-skill complementarity in production, our model show that to meet this pessimistic result, the stock of capital would have to rise continuously until 2020 at an annual rate of $7.8 \%$ that is 1.6 faster than its highest historical annual rate observed in the period 1982-1996. 


\section{Conclusion}

In this paper we analyse wage inequality and decompose the shifts in the relative demand for skilled workers into a skill-biased technological change effect and a capital-skill complementarity effect. We estimate the skill-wage premium in the Netherlands from 1969 to 1996 and find that between 1969-1982 demand shifts are due to skill-biased technological change mainly while since 1982, the capitalskill complementarity explanation accounts for $1 / 3$ of the shifts in the demand for skilled workers, SBTC accounting for $2 / 3$. The capital-skill complementarity effect is the result not only of increased capital stock but also the result of the perversive effect of the decrease in the share of unskilled workers in the costs of production. Using forecasts of the relative supply of skilled workers we predict the relative wage of skilled workers to 2020 for different scenarios of the change in the stock of capital. If the stock of capital increases steadily at a yearly rate of $5 \%$ (its highest historical annual rate, i.e. between 1985-1996) wage inequality would rise by $33 \%$ in 2020 . The rising wage inequality results from shifts in the relative demand for skilled workers initiated for $3 / 4$ by the capital-skill complementarity resulting itself from the ever decreasing share of unskilled workers. If however, the stock of capital grows at its average annual rate observed between 1969-1996, i.e. $2.7 \%$, wage inequality would increase by $20 \%$ only and $60 \%$ of the demand shifts would be induced by the capital-skill complementarity.

Though one may conclude that the race between schooling and technology, e.g. Tinbergen (1975) is lost to schooling, as Jacobs (2003) acknowledges, the position of unskilled workers is less undermined by skill-biased technological change than by persistently cheaper capital. Ironically and in accordance with the "importance of being unimportant" law of derived demand proposed by Marshall (1920), what harms the position of unskilled workers even more is the decrease of their share in total costs that accompanies decrease in the price of capital. 


\section{References}

Acemoglu, D. (2002): "Technical Change, Inequality and the Labor Market," Journal of Economic Literature, 40(1), 7-72.

Allen, R. (1938): Mathematical Analysis for Economists. London: Macmillan.

Autor, D., F. Katz, and A. Krueger (1998): "Computing Inequality: Have Computers Changed the Labor Market?," Quarterly Journal of Economics, 113(4), 1169-213.

Berman, E., J. Bound, and Z. Griliches (1994): "Changes in the Demand for Skilled Labor Within US Manufacturing: Evidence from Annual Survey of Manufactures," Quarterly Journal of Economics, 109(1), 367-97.

Berndt, E., and L. Christensen (1973): "The Translog Function and the Substitution of Equipment, Structures, and Labor in U.S. Manufacturing 1929-68," Journal of Econometrics, 1(1), 81-114.

Binswanger, H. (1974): "The Measurment of Technical Change Biases with Many Factors of Production," American Economic Review, 64(6), 964-76.

Bound, J., And G. Johnson (1992): "Changes in the Structure of Wages During the 1980's: An Evaluation of Alternative Explanations," American Economic Review, 82(3), 371-92.

Brown, M., and J. De Cani (1963): "Technological Change and the Distribution of Income," International Economic Review, 4, 289-309.

David, P., and T. Van De Klundert (1965): "Biased Efficiency Growth and Capital-Labor Substitution in the US, 1899-1960," American Economic Review, $55,357-93$. 
Grant, J. (1979): "Labor Substitution in U.S. Manufacturing," Ph.D. thesis, Michigan State University.

Griliches, Z. (1969): “Capital-Skill Complemementarity," Review of Economics and Statistics, 51(4), 465-8.

Hamermesh, D. (1992): "The Demand for Labor in the Long Run.," in Handbook of Labor Economics., ed. by O. Ashenfelter, and R. Layard, pp. 429-71. Amsterdam: North Holland.

(1993): Labor Demand. Princeton, New Jersey: Princeton University Press.

JAcobs, B. (2003): "The Lost Race Between Schooling and Technology," Mimeo.

Johnson, G. (1997): "Changes in Earnings Inequality: The Role of Demand Shifts," Journal of Economic Perspectives, 11(2), 41-54.

Katz, L., And K. MurPhy (1992): "Changes in Relative Wages, 1963-1987: Supply and Demand Factors," Quarterly Journal of Economics, 107(1), 35-78.

Kennedy, C. (1964): "Induced Bias in Innovation and the Theory of Distribution," Economic Journal, 74, 541-47.

Krusell, P., L. Ohanian, V. Ríos-Rull, and G. Violante (2000): “CapitalSkill Complementarity and Inequality: A Macroeconomic Analysis," Econometrica, 68(5), 1029-53.

Marshall, A. (1920): Principles of Economics. London: Macmillan, 8th edn.

Rosen, S. (1968): "Short-Run Employment Variation on Class-I Railroads in the United States, 1947-1963," Econometrica, 36, 511-29.

SAto, R. (1970): "The Estimation of Biased Technical Progress and the Production Function," International Economic Review, 11, 179-208. 
Tinbergen, J. (1975): Income Distribution: Analysis and Policies. Amsterdam: North-Holland.

Varian, H. (1984): Microeconomic Analysis. New York: Norton and Company, 2nd edn.

Yunn, K. (1991): "Economic Growth, Technological Change Biases, and the Elasticity of Substitution: A Test of the de la Granville Hypothesis," Review of Economics and Statistics, pp. 340-6.

Zellner, A. (1962): "An Efficient Method of Estimating Seemingly Unrelated Regressions and Tests for Aggregation Bias," Journal of the American Statistical Association, 57, 585-612.

— (1963): "Estimators for Seemingly Unrelated Regression Equations: Some Exact Finite Sample Results," Journal of the American Statistical Association, 58, 977-92. 


\section{Appendix A}

The AES, denoted $A E S_{u s}$ and $A E S_{K, s}$ and $A E S_{K, u}$, are derived as $A E S_{i g}=$ $\left|G_{i g}\right| /|G|$ where $|G|$ is the determinant of the symmetric matrix $G$ defined as follows:

$$
G=\left[\begin{array}{cccc}
0 & S_{K} & S_{u} & S_{s} \\
S_{K} & \beta_{K, K}+S_{K}^{2}-S_{K} & & \beta_{K, s}+S_{s} \times S_{K} \\
S_{u} & & \beta_{u u}+S_{u}^{2}-S_{u} & \\
S_{s} & \beta_{K, s}+S_{s} \times S_{K} & & \beta_{s s}+S_{s}^{2}-S_{s}
\end{array}\right]
$$

and $\left|G_{i g}\right|$ is the cofactor of $G_{i g}$ in $G$.

The Allen partial elasticities of substitution register the effect on the relative quantity of two factors, say $i$ and $g$, of a change in the relative price of this two factors where output and prices of other factors are held constant. 


\section{Appendix B}

Table 5: Grid-search for the restricted parameters.

\begin{tabular}{cc|rrrr}
\hline \hline \multirow{4}{*}{$\min \sum_{t}\left(\widehat{\frac{w_{s}}{w_{u}}}, t-\frac{w_{s}}{w_{u}}, t\right)^{2}$} & \multicolumn{4}{|c}{$\beta_{s K}+\beta_{u K}$} \\
& 0 & 0.01 & 0.02 & 0.03 \\
\hline \multirow{4}{*}{$\beta_{u u}$} & 0.05 & 0.0373 & 0.0371 & 0.0366 & 0.0362 \\
& 0.06 & 0.0317 & 0.0313 & 0.0310 & 0.0308 \\
& 0.07 & 0.0293 & 0.0291 & 0.0289 & 0.0308 \\
& 0.08 & 0.0315 & 0.0315 & 0.0316 & 0.0317 \\
& 0.09 & 0.1430 & 0.1492 & 0.1617 & 0.1704 \\
\hline \hline
\end{tabular}




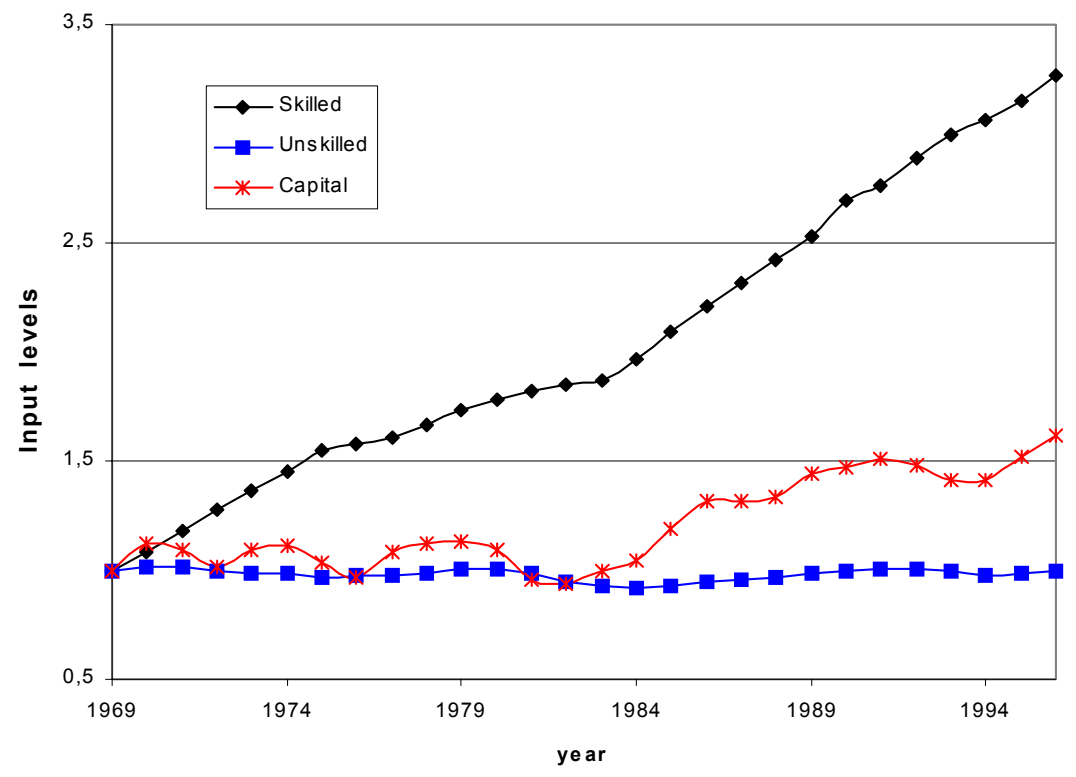

Figure 1: Time-series of Capital stock, supply of skilled and unskilled labour in the Netherlands 1969-1996.

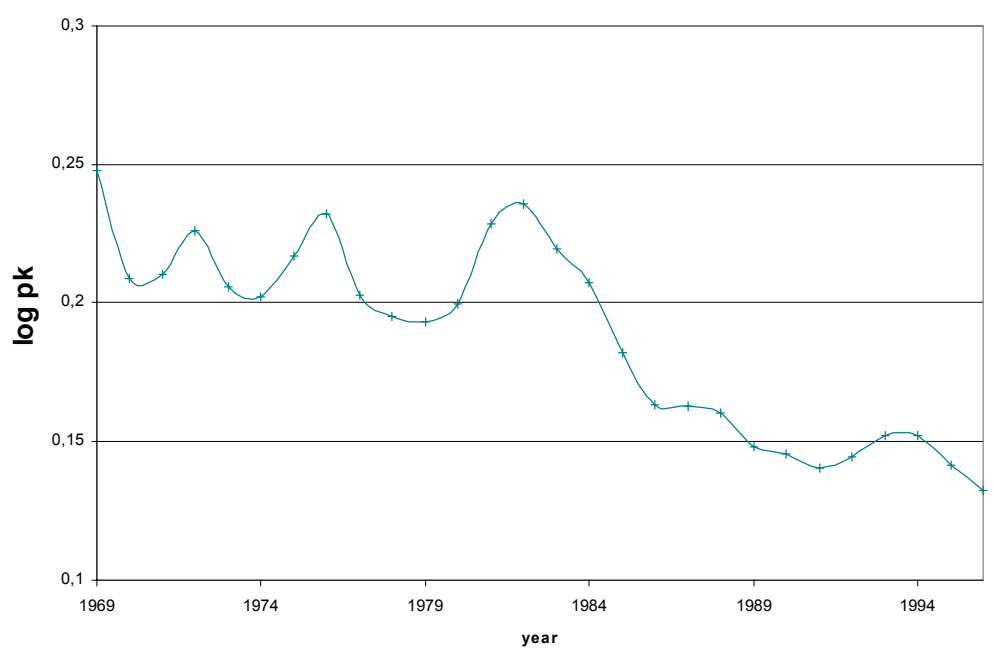

Figure 2: Price of capital 


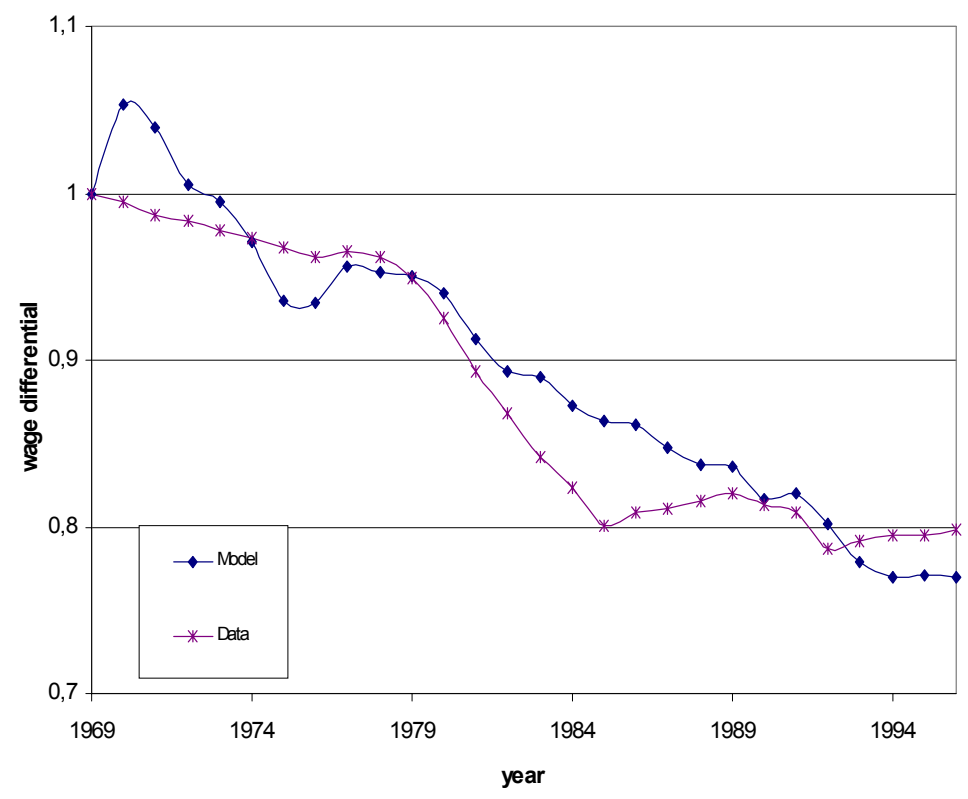

Figure 3: Skilled versus unskilled wages

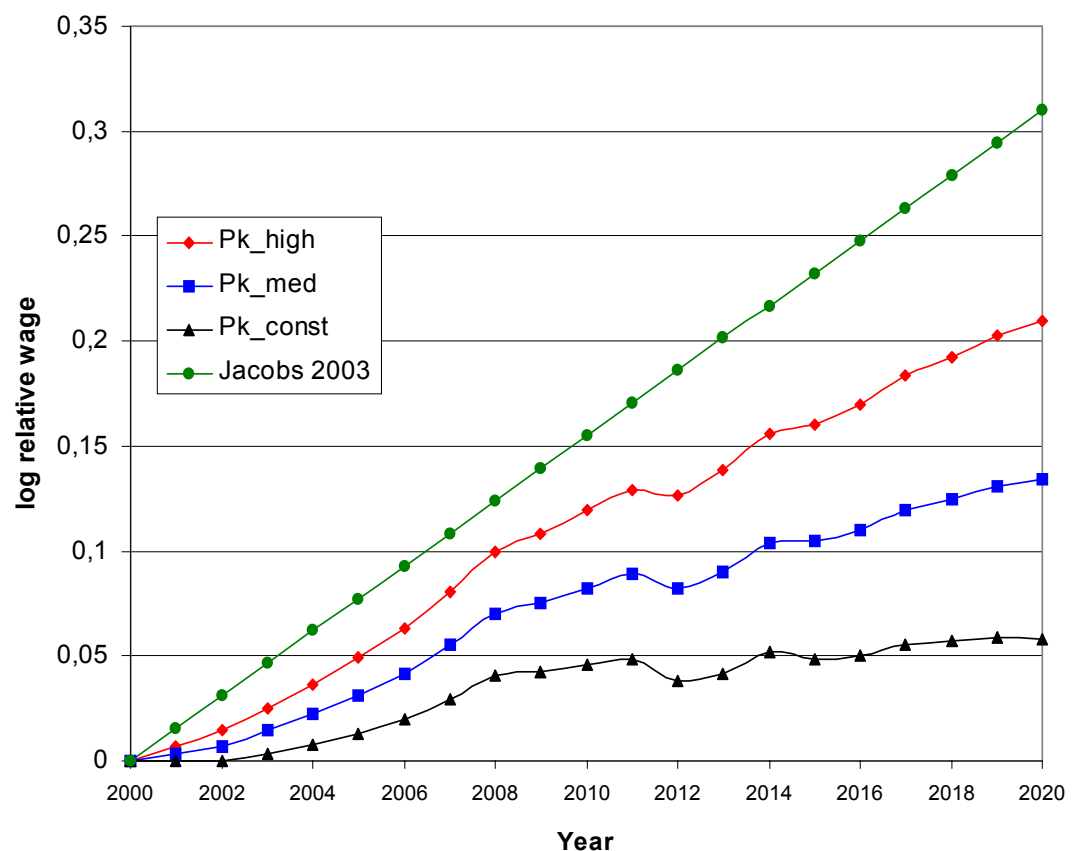

Figure 4: Ex-ante predictions of wage differentials in the Netherlands 2000-2020. 